TADEUSZ LEWASZKIEWICZ

Uniwersytet im. Adama Mickiewicza w Poznaniu

\title{
PROBLEMY NORMALIZACJI I KODYFIKACJI W HISTORII JĘZYKA DOLNOŁUŻYCKIEGO I JĘZYKA GÓRNOŁUŻYCKIEGO
}

\section{Uwagi wstępne}

O standaryzacji języków łużyckich, tj. kształtowaniu się ogólnego/literackiego (w polskiej terminologii językoznawczej) języka dolnołużyckiego i ogólnego/literackiego języka górnołużyckiego, wypowiadało się wielu autorów. Standaryzację pojmuję jako normalizację języka połączoną z jego kodyfikacją. Jeśli przez kodyfikację rozumiemy zapis norm (i ewentualnie ich wariantów) ortograficznych i językowych w postaci dawnych traktatów ortograficznych, gramatyk, słowników i różnego typu poradników językowych (np. słowników ortoepicznych, poprawnej wymowy, ortograficznych), to możemy stwierdzić, że w historii języków słowiańskich proces normalizacji (przeprowadzonej przynajmniej częściowo) dosyć znacznie wyprzedzał kodyfikację językową. O dokładniejszej kodyfikacji językowej w świecie słowiańskim można mówić dopiero od XVI wieku, chociaż znane są jej przykłady już w średniowieczu. W historii języka czeskiego dziełem kodyfikującym pisownię był traktat Jana Husa De orthographia bohemica (1411 lub 1412 r). Wcześniej, tj. w drugiej połowie XIV wieku, powstały wierszowane słowniki Klareta, które głównie rejestrowały słownictwo z różnych dziedzin życia, ale wydaje się, że Klaretowi chodziło również o skodyfikowanie słownictwa. Około 1440 roku powstał traktat o ortografii polskiej Jakuba Parkoszowica. Z XV wieku zachowało się też kilka słowniczków. Jak widać, pierwsze opracowania kodyfikujące język czeski i język polski pojawiły się kilkaset lat po rozpoczęciu procesu kształtowania się języków ogólnych/literackich. Warto też pamiętać o tym, że czeski język ogólny/literacki istniał już właściwie pod koniec XIII wieku, a w drugiej połowie XIV wieku powstał pełny przekład Biblii. Za czasów Husa czeski reprezentował wysoki poziom sprawności funkcjonalnej. Polski język literacki ukształtował się później. Z pewnością pojawiały się przed XV wiekiem teksty na wysokim poziomie artystycznym (o czym świadczą przynajmniej dwa zabytki: Bogurodzica i Kazania świętokrzyskie); język polskiego piśmiennictwa doskonalił się w XV wieku (również pod silnym wpływem czeskiego), ale wysoki poziom rozwoju środków stylistycznych osiągnął dopiero w połowie XVI wieku. 
O języku staro-cerkiewno-słowiańskim możemy mówić w zasadzie tylko do XII wieku. Późniejsza forma tego języka to język cerkiewnosłowiański. O normalizację staro-cerkiewno-słowiańskiego i jego późniejszych odmian regionalnych troszczyły się różne szkoły językowe w Bułgarii, Macedonii i Serbii, ale nie była to typowa działalność kodyfikacyjna w postaci gramatyk i słowników. Najważniejszą próbę kodyfikacji cerkiewnosłowiańskiego podjął Melecjusz Smotrycki w swojej gramatyce z roku 1619. Mimo to właściwie przez cały XVII wiek ścierały się normy językowe trzech ośrodków piśmiennictwa cerkiewnosłowiańskiego ruskiej redakcji: wileńskiego, kijowskiego i moskiewskiego. Do normalizacji słownictwa najbardziej przyczynił się - jak się wydaje - Stownik cerkiewnostowiańsko-grecko-łaciński (Moskwa 1704). W XVIII wieku głównym źródłem normalizacji był cerkiewnosłowiański redakcji moskiewskiej. W tym stuleciu język ten stawał się w świecie słowiańskim stopniowo wyłącznie językiem liturgii prawosławnej.

Jak z powyższych uwag wynika, ukształtowanie się języka ogólnego/języka piśmiennictwa/języka literackiego może mieć miejsce także w sytuacji, gdy brak jest traktatów ortograficznych, gramatyk i słowników. Po prostu piszący starali się naśladować pisownię i język znanych im tekstów. Moim zdaniem, można zatem mówić o „kodyfikacji tekstowej” języka, jeśli jakiś prestiżowy tekst (np. przekład fragmentaryczny lub pełny Biblii) służy jako wzór zachowań językowych, podobnie jak traktat ortograficzny, gramatyka czy słownik. Niewątpliwie wzorowano się również na języku mówionym ludzi cieszących się prestiżem językowym. Kodyfikacja jest jednak konieczna, jeśli chce się osiągnąć wysoki poziom sprawności i kultury językowej. Do takiego stanu dochodzi się, gdy naród - posługujący się konkretnym językiem - egzystuje w korzystnych warunkach społeczno-kulturalnych.

W historii języków słowiańskich podstawę języka ogólnego/literackiego mógł stanowić jeden dialekt (np. język czeski - dialekt Pragi i okolicy, język nowobułgarski - głównie dialekt wschodniobułgarski, język rosyjski - dialekt/język potoczny Moskwy i okolicy) lub kilka dialektów (np. dialekt wielkopolski i małopolski, od XVI wieku również mazowiecki w historii języka polskiego). Szersza podstawa dialektalna narzuca konieczność większej intensyfikacji ścierania się norm niż w wypadku wzorowania się na dialekcie zajmującym mniejsze terytorium.

Zagadnienie normalizacji i kodyfikacji języków narodowych - w tym również słowiańskich - jest bardzo skomplikowane. Trudne jest zarówno śledzenie tych procesów w ewolucji języka, jak i ocena sytuacji językowej we współczesności. Nie będę zajmował się dalej zagadnieniami teoretycznymi, ponieważ napisano już bardzo dużo na ten temat, a mimo to badacze często różnią się $\mathrm{w}$ ocenie zagadnień ogólnych i szczegółowych. Przykładowo warto wymienić kilka pozycji bibliograficznych: Urbańczyk 1977, Tołstoj 1998, Gutschmidt 2002.

W dalszej części artykułu przedstawię pokrótce dzieje normalizacji i kodyfikacji języka dolnołużyckiego i języka górnołużyckiego. Problematyka ta jest znana w literaturze sorabistycznej. Moje wywody nie będą jednak tylko przypomnieniem pewnych faktów z historii języków łużyckich. Za istotne uważam w moich rozważaniach dwie kwestie: charakter języka przekładu NT M. Jakubicy (1548) oraz ocenę kodyfikacji pisowni łużyckiej z połowy XIX wieku, tzw. pisowni analogicznej. Poddam również krytyce stanowisko teoretyków i historyków języków literackich (w tym również dolnołużyckiego i górnołużyckiego), którzy za najważniejszy czynnik w procesie formowania się języka literackiego 
uznają jego dialektalną genezę i kształtowanie się norm językowych, tj. normalizację, nie doceniają zaś lub w ogóle nie biorą pod uwagę intelektualizacji tworzywa dialektalnego pod wpływem języków wysokoprestiżowych.

Dzieje normalizacji i kodyfikacji dolnołużyckiego i górnołużyckiego dzielę na dwa etapy: do drugiej wojny światowej i po 1945 roku, kiedy zaistniały całkowicie nowe warunki rozwoju obu języków.

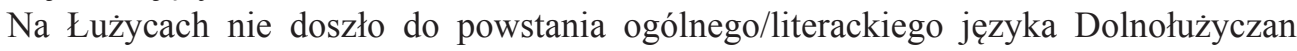
i Górnołużyczan. Zadecydowały o tym duże różnice między systemami językowymi zespołu dialektów dolnołużyckich i zespołu dialektów górnołużyckich. Zwolennikiem upowszechnienia górnołużyckiego na Dolnych Łużycach, przynajmniej w sferze życia religijnego, był Michał Frencel (1628-1706). W drugiej połowie XIX wieku Michał Hórnik zachęcał Dolnołużyczan do podjęcia wysiłków na rzecz językowego zbliżenia z Górnołużyczanami. Po drugiej wojnie światowej wprowadzono do pisowni dolnołużyckiej zmiany, które były wzorowane na pisowni i wymowie górnołużyckiej. Dolnołużyczanie działania te uznali po 1989 roku za wyraz ekspansjonizmu Górnołużyczan. Do zjednoczenia Niemiec oficjalnie mówiło się o jednym narodzie łużyckim. W latach 90. ubiegłego stulecia wielu Dolnołużyczan doszło do wniosku, że nie są Dolnołużyczanami, lecz Wendami, chociaż dosyć często określenie to traktowano kiedyś (głównie na Górnych Łużycach) jako obraźliwe.

\section{Zarys dziejów normalizacji i kodyfikacji dolnołużyckiego do drugiej wojny światowej}

Najwcześniejszym zabytkiem łużyckiego obszaru językowego jest przekład NT Mikławša Jakubicy (1548). Przynajmniej do lat 60. XX wieku powszechnie przyjmowano w slawistyce, że jest to przekład na dialekt wschodnio-dolno-łużycki. Elementy typu polskiego interpretowano jako część składową przejściowego charakteru dialektu M. Jakubicy (między Żarami a Lubskiem), który znajdował się między typowymi dialektami dolnołużyckimi i polskimi. Liczne czeskie cechy językowe wiązano z czeskim NT, z którego M. Jakubica miał korzystać. Później okazało się (dzięki badaniom H. Schuster-Šewca), że w zabytku poświadczone są dosyć często językowe właściwości zachodnio-dolno-łużyckie i także górnołużyckie (głównie w słownictwie). Przez dziesięciolecia w literaturze naukowej zastanawiano się, czy tekst M. Jakubicy mógł stanowić podstawę dolnołużyckiego lub nawet ogólnołużyckiego języka literackiego. Ponieważ do tego nie doszło, brano pod uwagę względy finansowe, zaginięcie rękopisu oraz fakt, że przekład reprezentował dialekt peryferyjny, a zatem nie mógł liczyć na akceptację językową nie tylko na całych Łużycach, ale nawet na Dolnych Łużycach.

Moim zdaniem, przekład M. Jakubicy nie mógł być wzorem norm językowych, ponieważ reprezentował język bardzo mieszany, tj. sztuczny. Nie istniał żywy język, w którym poświadczone byłyby bardzo liczne (liczące setki przykładów) warianty językowe (fonetyczne, morfologiczne, składniowe i leksykalne, np. jego||jogo||jeho, gnjazdo\|gnjezdo, gwjazda\|gwjezda, ryćédz\|ryćez, słońce\|slońce||slunce, końcówka -me\|-my w 1. os. lm., $k a z ̌ d y \| k u z ̌ d y$, prajić||prawić. Oprócz tego w tekście występują osobne elementy zachodnio-dolno-łużyckie, górnołużyckie i czeskie. Jest mało prawdopodobne, aby wszystkie polskie 
elementy językowe, poświadczone w tekście M. Jakubicy, istniały w dialekcie wschodnio-dolno-łużyckim. Być może był to język wymieszanej ludności dolnołużycko-polskiej z niektórych wsi położonych na wschód od Nysy. Język NT (1548) świadczy o niedostatkach kompetencji językowej tłumacza. M. Jakubica nie znał dobrze żadnego dialektu łużyckiego. Niczego nie możemy powiedzieć o jego pochodzeniu narodowym. Mógł być Dolnołużyczaninem lub Górnołużyczaninem, Niemcem, Czechem, Polakiem lub pochodził z mieszanej narodowo rodziny słowiańskiej (łużycko-czeskiej, łużycko-polskiej, polsko-czeskiej), niemiecko-łużyckiej, niemiecko-czeskiej, niemiecko-polskiej. Mógł urodzić się między Żarami a Lubskiem, koło Szprotawy, w pobliżu Mużakowa, Chociebuża, na Górnych Łużycach, w Czechach lub na Śląsku.

Żadnej roli w kształtowaniu się języka dolnołużyckiego nie odegrał rękopis Psałterza z Wolfenbüttel z drugiej połowy XVI wieku, reprezentujący południowo-zachodni dialekt okolic Łukowa. Pierwsza drukowana książka łużycka, Wendisches Gesangbuch [...]. Auch der Kleine Catechismus (1574) Albina Mollera, przyczyniła się wprawdzie do podniesienia ogólnej sprawności językowej dolnołużycczyzny, ale jej język - peryferyjny dialekt zachodnio-dolno-łużycki (z okolic Lubniowa i Lubina) - nie stał się podstawą literackiej dolnołużycczyzny. Następną próbę podniesienia języka gwarowego do godności języka literackiego podjął Andreas Tharaeus vel Tara. Wydał on w 1610 roku książeczkę Enchiridion Vandalicum. Jest to tłumaczenie Małego katechizmu Marcina Lutra, do którego Tara dołączył zasady pisowni dolnołużyckiej. Chciał również wydać postyllę, gramatykę dolnołużycką i słownik. Zamiaru tego nie zrealizował, ale miał świadomość, że normalizacja języka ludowego nie będzie możliwa bez odpowiednich opracowań gramatycznych i leksykograficznych. Dialekt wsi Storkow, z której Tara pochodził, od dawna już nie istnieje.

W 1650 roku powstała rękopiśmienna gramatyka Jana Chojnana, znana na Dolnych Łużycach z licznych odpisów. Jej autor podjął próbę kodyfikacji dialektu chociebuskiego, który w XVIII wieku - dzięki NT Jana B. Fabriciusa (1709) i ST Jana B. Fryca (1796) stał się podstawą dolnołużyckiego języka literackiego. Ważne jest to, że drukowana gramatyka Johanna G. Hauptmanna (Niederlausitzsche Wendische Grammatica [...], Lübben 1761) oparta jest na języku NT J.B. Fabriciusa, a zatem skodyfikował on literacką postać dolnołużycczyzny na podstawie tekstu biblijnego. Drugim dziełem kodyfikującym język dolnołużycki miał być słownik (Lexicon Vandalicum, 1731), który jednak pozostał w rękopisie.

Do połowy XIX wieku piśmiennictwo dolnołużyckie miało prawie wyłącznie biblijno-religijny charakter. Ważnym czynnikiem rozwoju języka stało się czasopiśmiennictwo. Od 1848 roku ukazywał się tygodnik Bramborski serbski casnik, później pojawiły się również inne czasopisma. Coraz częściej pisarze dolnołużyccy ogłaszali utwory literackie o świeckiej tematyce. Działalnością kodyfikacyjną w zakresie ortografii zajął się Jan B. Tešnaŕ. W 1847 roku ukazał się słownik dolnołużycko-niemiecki Johanna G. Zwahra (Niederlausitzisch-wendisch-deutsches Handwörterbuch, Spremberg 1847), ale z punktu widzenia kodyfikacji słownictwa nie była to publikacja na wysokim poziomie. Do połowy XX wieku nie istniał zatem odpowiedni słownik normatywny dolnołużyckiego. Słownik Arnošta Muki (Stownik delnoserbskeje rěce a jeje narěcow, t. 1-2, Petersburg-Praha 1911-1928) nie miał charakteru normatywnego.

W drugiej połowie XIX wieku Moritz H. A. Ebert i Miertyn Moń napisali wprawdzie gramatyki języka dolnołużyckiego, ale nie oddziaływały one na normalizację dolnołużycczyzny, ponieważ nie ukazały się drukiem (Wölke 2005). 
W kodyfikacji pisowni i gramatyki dolnołużyckiej ważną rolę odegrała publikacja Bogumiła Šwjeli Lehrbuch der niederwendischen Sprache. Grammatik, Heidelberg 1906; ukazała się ona ponownie w 1952 roku, przeredagowana przez Frida Mětška.

Przed 1945 rokiem wydrukowano niewiele tekstów dolnołużyckich w pisowni analogicznej. Zapożyczenia słowiańskie (głównie czeskiego pochodzenia) przenikały do dolnołużyckiego głównie za pośrednictwem górnołużyckiego. Dolnołużycki przejął również liczne rodzime neologizmy górnołużyckie (Pohončowa 2002). Wpływy leksyki dolnołużyckiej na górnołużycką są rzadko poświadczone.

\section{Zarys dziejów normalizacji i kodyfikacji górnołużyckiego do drugiej wojny światowej}

Dwa najwcześniejsze druki górnołużyckich protestantów (Katechizm Wjacława Warichiusa z 1595 roku i Psalmy pokutne Hrjehora Martiniego z 1627 roku) reprezentują dialekt lubiński, używany na południowy wschód od Budziszyna. Warto wspomnieć, że W. Warichius zamieścił we wstępie zasady pisania i czytania.

Późniejsze piśmiennictwo protestanckie oparło się jednak na dialekcie budziszyńskim. Jego podstawy stworzył M. Frencel, który w 1670 roku wydał przekład Ewangelii wedtug Mateusza i Marka oraz w 1706 roku NT. We wstępie do przekładu z 1670 roku zamieścił uwagi o ortografii (opartej na wzorach czeskich) oraz wiersz pochwalny Jurija Ludoviciego, który skodyfikował dialekt budziszyński w rękopiśmiennej gramatyce (Rudimenta grammaticae Sorabo-Vandalicae idiomatis Budissinatis delineata), zapewne upowszechnianej w odpisach. Pisownia „czeska” M. Frencla nie uzyskała aprobaty wśród duchownych protestanckich, którzy poparli kodyfikację pisowni Zachariasa Běrlinka (Didascalia seu orthographia Vandalica. Das ist Wendische Schreib-und-Lese-Lehr auf das Budissinische Idioma oder Dialectum mit Fleiß gerichted, Budissin 1689). Z. Běrlink korzystał z zasad pisowni niemieckiej.

Główną siłą napędową rozwoju języka literackiego protestantów stała się Biblia z 1728 roku. Zespół czterech tłumaczy i redaktorów zrewidował przekład NT M. Frencla, Psałterz i inne fragmenty ST. Ich dziełem translatorskim jest większość ksiąg ST. Poprawki wniesione do tych przekładów dotyczyły głównie ortograficznej i fonetycznej strony tekstów, zmiany zaś gramatyczne i leksykalne były nieliczne. Tłumacze pochodzili z różnych miejscowości budziszyńskiego obszaru dialektalnego, ponieważ stany górnołużyckie życzyły sobie, aby Biblia oparta była na cechach językowych całego dialektu budziszyńskiego. Przekład NT M. Frencla nie mógł być wzorem norm ponaddialektalnych, ponieważ dominowały w nim cechy językowe dialektu, którym posługiwano się na południe i na wschód od Budziszyna. W czasie pracy nad Biblią (1728) ukazała się gramatyka Jurija Mateja (G. Matthaei, Wendische Grammatica [...], Budissin 1721). Kodyfikowała ona pisownię i gramatykę, zawierała też słowniczek niemiecko-górnołużycki. Nie ulega wątpliwości, że zespół tłumaczy Biblii korzystał z tej gramatyki.

Górnołużyccy katolicy oparli się w swoim piśmiennictwie na dialekcie Kulowa i okolicy, około 40 kilometrów na północny zachód od Budziszyna. Został on skodyfikowany w gramatyce Jakuba X. Ticina (Principia linguae Wendicae, Pragae 1679), który posłużył 
się nim w przekładzie Katechizmu Piotra Canisia (1685). Największe zasługi w rozwoju i normalizacji językowej piśmiennictwa katolickiego ma Jurij H. Swětlik, thumacz Perykop (1690), całej rękopiśmiennej Biblii (1688-1711) i wydawca innych tekstów religijnych, a także autor Słownika łacińsko-górnołużyckiego (1721) i kilku rozprawek o pisowni i fonetyce. Słownik, przygotowany na podstawie nowej edycji Perykop z 1699 roku, był źródłem norm leksykalnych w piśmiennictwie katolickim. Jego język można uznać za kulowski, choć spotyka się w nim również elementy innych dialektów katolickich.

Politykę zbliżenia kulowskiej podstawy języka literackiego do dialektu Chrósćic zrealizował później biskup Jakub Wóski, który m.in. w 1750 roku wydał ponownie Perykopy Swětlika. Zastąpił w nich przede wszystkim formy kulowskie elementami dialektu Chrósćic. Ponieważ Chrósćice leżą bliżej Budziszyna niż Kulow, różnice fonetyczno-gramatyczne między językiem piśmiennictwa protestantów i katolików się zmniejszyły. Dalej wyraźnie różniły się dwa warianty języka piśmiennictwa pod względem ortografii: protestanci od końca XVII wieku wzorowali się na pisowni niemieckiej (jedynie M. Frencel na początku swojej działalności przekładowej oparł się głównie na zasadach pisowni czeskiej), katolicy zaś mieli od czasów J.X. Ticina i J.H. Swětlika pisownię wzorowaną na czeskiej. Wspólną cechą pisowni druków protestanckich i katolickich był gotycki kształt liter.

W niewielkim stopniu na normalizację wariantu piśmiennictwa protestanckiego mogły wpłynąć rękopiśmienne prace XVIII-wiecznych autorów: Johanna F.G. Schmutza (gramatyka i słownik), Johanna M. Georga (gramatyka). W drugiej połowie XVIII wieku duchowni katoliccy korzystali z rękopiśmiennych opracowań Jana J.P. Hančki, tj. z gramatyki i słownika. Wpłynęły one niewątpliwie na kształt językowy publikacji Bosćana T. Měta. W pierwszej połowie XIX wieku protestanci cenili opracowania językowe Handrija Lubjenskiego (rękopisy gramatyki i słownika) oraz wydaną gramatykę (1830) Handrija Zejlera. O gramatykach tych szczegółowo pisze Sonja Wölkowa (Wölke 2005).

Do połowy XIX wieku w piśmiennictwie górnołużyckim dominowały wyraźnie teksty religijno-biblijne, chociaż w latach 1809-1812 ukazywały się pierwsze miesięczniki polityczno-informacyjne, a pod koniec lat dwudziestych Zejler zaczął pisać utwory poetyckie. O wzroście znaczenia piśmiennictwa świeckiego (głównie prasy i literatury pięknej) w kulturze łużyckiej można mówić dopiero od połowy XIX wieku, tj. od epoki odrodzenia narodowego. Od tego czasu łużyckie języki literackie przekształcały się w języki literackie nowego typu.

Program językowego zjednoczenia Górnołużyczan, poparty przez wpływowe osobistości obu wyznań, stworzyła dopiero Macierz Łużycka, koordynująca od 1847 roku działania budzicieli łużyckiego odrodzenia narodowego i kulturalnego. Z jej inicjatywy Křesćan B. Pful (protestant) skodyfikował jednolity (bezwyznaniowy) język górnołużycki w zakresie ortografii, wymowy, morfologii i słownictwa w następujących pracach: Hornjotužiski serbski prawopis z krótkim rěčničnym přehladom (Budyšin 1848); Łužyski serbski słownik (Budyšin 1866); Laut und Formenlehre der oberlausitzisch-wendischen Sprache. Mit besonderer Rücksicht auf das Altslawische (Bautzen 1867). Składnię górnołużycką opisał i skodyfikował Jurij Libš w pracy Syntax der wendischen Sprache in der Oberlausitz (Bautzen 1884). Wspólny język Górnołużyczan prawie wyłącznie opiera się na tradycji językowej piśmiennictwa protestanckiego.

Do przezwyciężenia dualizmu językowego Górnołużyczan przyczyniła się tzw. pisownia analogiczna, tj. analogiczna do pisowni słowiańskich (głównie czeskiej i polskiej), 
opartych na antykwie. W rzeczywistości ten typ pisowni nazywano zwykle pisownią czeską. Pionierem nowej pisowni był Jan P. Jordan, który po raz pierwszy zastosował ją w 1837 roku. Napisał on również normatywną gramatykę Grammatik der wendisch-serbischen Sprache in der Oberlausitz. Im Systeme Dobrowskýs abgefasst (Prag 1841). Podobny system pisowni opracował Jan A. Smoler; posłużył się nią w zbiorze pieśni ludowych Volkslieder der Wenden in der Ober -und Nieder-Lausitz - Pjesnički hornych a delnych Łužiskich Serbow (Grimma 1841-1843, wspólnie z Joachimem L. Hauptem), w elementarzu Mały Serb (Budyšin 1841) oraz w Němsko-serbskim słowniku (Budyšin 1843). Projekt K.B. Pfula to kompromis między propozycją pisowni J.P. Jordana i J.A. Smolera. Zwolennikami nowej pisowni byli m.in. H. Zejler i M. Hórnik.

Cechy pisowni analogicznej to: 1. antykwa zamiast szwabachy (jak u Słowian z kręgu kultury rzymskiej), 2. specyficzne grafemy (czeskie litery č, š, ž, ř, ě; polskie litery ó, ł, dź, ń, chociaż podobne grafemy występowały już w łużyckiej tradycji piśmienniczej) i - moim zdaniem - najważniejsza cecha pisowni analogicznej: 3. zasada pisowni etymologicznej zamiast tradycyjnej łużyckiej pisowni fonetycznej, np. w pisowni analogicznej chory, hłowa, hdźe, nahły, hnić, wzać, hwězda, tři, bóh zamiast dawnej pisowni kory/khory, łowa, ḋ̉e, nały, nić, zać, vjesda, cy/ci, bo.

Reforma ortografii miała na Łużycach wielu przeciwników. Krytykowali ją głównie protestanci, którzy nie chcieli zrezygnować z tradycyjnej ortografii piśmiennictwa religijno-biblijnego. W 1867 roku Jan Stoš, kowal z zawodu, zbierał w okolicy Budziszyna podpisy pod protestem przeciw reformie pisowni. Nową ortografię propagował rocznik „Časopis Maćicy Serbskeje”, zaakceptowało ją wielu pisarzy, w pisowni analogicznej wydrukowano katolicki NT (1896) Jurija Łusčanskiego i M. Hórnika. W piśmiennictwie religijnym protestantów i w Serbskich Nowinach dominowała jednak do 1937 roku nieco zmieniona szwabacha. Pismo było bardziej okrągłe niż dawne pismo gotyckie (widać tutaj nawiązanie do antykwy), wprowadzono czeską literę ě, w dużym stopniu stosowano zasadę pisowni etymologicznej, tj. pisano $h d y, w z a c ́$ itd. zamiast $d y, z a c ́$. A zatem spotykany niekiedy w literaturze naukowej pogląd o całkowitym odrzuceniu przez protestantów zasad pisowni analogicznej jest niesłuszny. Pisownię protestancką od przełomu XIX/XX wieku do wprowadzonego przez nazistów w 1937 roku zakazu drukowania tekstów łużyckich można określić jako pisownię półanalogiczną. Została ona wyparta bezwyjątkowo przez pisownię analogiczną dopiero po drugiej wojnie światowej.

Protestanci sprzeciwiali się nie tylko „czeskiej” pisowni, ale również wypowiadali się przeciw leksykalnym zapożyczeniom z języków słowiańskich - głównie z czeskiego, rzadko z polskiego, sporadycznie z innych języków słowiańskich. K.B. Pful przesadził z propozycjami słowiańskich (zwłaszcza czeskich) zapożyczeń leksykalnych: w jego dziele leksykograficznym znajduje się około 1100 bohemizmów i prawie 300 polonizmów. Górnołużycki przyswoił sobie spośród polonizmów zaledwie kilkadziesiąt haseł. Ile bohemizmów leksykalnych K.B. Pfula przejął język górnołużycki, nie wiadomo. Renata Bura (2015) przeanalizowała 432 górnołużyckie terminy naukowe pochodzenia czeskiego, z których 132 zna współczesna górnołużycczyzna.

Wprowadzanie rodzimych neologizmów i zapożyczeń słowiańskich było związane z silnym puryzmem językowym zwolenników łużyckiego odrodzenia językowego, którzy dążyli do radykalnego usunięcia z łużycczyzny niemieckich zapożyczeń leksykalnych i niemieckich wpływów na łużycki system gramatyczny. Przykładem wyidealizowanego 
(zeslawizowanego głównie pod czeskim wpływem) języka był katolicki przekład NT (1896). Nie miał on dużego wpływu na normalizację górnołużyckiego (nawet w piśmiennictwie religijnym katolików), ponieważ nie odzwierciedlał sytuacji komunikatywnej na Górnych Łużycach.

Wydaje się, że niechęć protestantów (szczególnie duchowieństwa) do pisowni analogicznej i zapożyczeń słowiańskich wynikała nie tylko z konserwatyzmu językowego, lecz także z przekonania, że nowatorstwo ortograficzno-językowe jest przejawem oddziaływania kultury katolickich Słowian. J.A. Smoler, K.B. Pful i inni słowianofile wyznania protestanckiego byli mocno krytykowani za uleganie wpływom słowiańskim, które części społeczności protestanckiej nasuwały przede wszystkim skojarzenia z katolicyzmem i prawosławiem, a nie z doskonaleniem ortografii języków łużyckich i ich sprawności językowej oraz stylistycznej.

W tym miejscu chciałbym częściowo krytycznie wypowiedzieć się o reformie łużyckiej ortografii z połowy XIX wieku, tj. o pewnym szkodliwym - moim zdaniem - aspekcie wprowadzenia pisowni analogicznej. Sądzę, że propozycja zastąpienia szwabachy antykwą zasługuje na aprobatę, ponieważ takim pismem posługuje się znaczna większość narodów Europy. Nie istniała bezwzględna konieczność przejęcia wszystkich liter z daszkami i ukośnymi kreseczkami, ale rzeczywiście przynajmniej częściowo zasady pisowni czeskiej i polskiej przyczyniły się do ustabilizowania łużyckiego systemu graficznego. Więcej jednak było $\mathrm{w}$ tym posunięciu reformatorów słowianofilskiej ideologii $\mathrm{i}$ antyniemieckości niż bezwzględnej potrzeby. Na ostrą krytykę zasługuje natomiast zakres zastąpienia zasady pisowni fonetycznej zasadą pisowni etymologicznej. Odtąd - zarówno Górnołużyczanie, jak i Dolnołużyczanie - często pisali poszczególne wyrazy inaczej niż je wymawiali. Pisownia bardzo oddziałuje na wymowę. Obecnie - w epoce pogarszania się sytuacji językowej na Łużycach - rozbieżność pisowni i wymowy powoduje, że wielu Łużyczan naśladuje w wymowie pisownię, przez co norma wymawianiowa niektórych wyrazów jest bardzo rozchwiana. Mówią po górnołużycku głównie katolicy. Do mówionej odmiany języka górnołużyckiego przenikają w związku z tym cechy fonetyczne dialektu katolickiego, pogłębiając jeszcze bardziej wariantywność wymowy. Dzisiaj nikt nie myśli o skutecznym unormowaniu wymowy górnołużyckiej i dolnołużyckiej. Najpierw należałoby ustalić uzus wymowy wielu wyrazów, zastanowić się nad normami wymawianiowymi, a następnie dokonać kodyfikacji. Kodyfikacja musiałaby aprobować często wariantywność wymowy, aby zasłużyć na miano racjonalnej. Obecnie w łużyckiej sytuacji językowej najważniejsze jest bowiem to, że ktoś w ogóle mówi, a nie to, jak ktoś mówi.

Kodyfikacja K.B. Pfula (głównie morfologiczna i leksykalna) po kilkudziesięciu latach zestarzała się. Należało wprowadzić do niej najistotniejsze zmiany. Nowym kodyfikatorem morfologii był Jurij Kral, autor Grammatik der wendischen Sprache in der Oberlausitz (Bautzen 1895); wydania z 1919 i 1925 roku zawierają drobne zmiany. Dzieło to traktowano jako źródło norm językowych do początku lat 50. XX wieku. Słownictwo na nowo pierwszy raz po K.B. Pfulu (1866) - skodyfikowali: Filip Rězak (Němsko-serbski wšowědny słownik hornjotužiskeje rěče/Deutsch-wendisches encyklopädisches Wörterbuch der oberlausitzer Sprache, Bautzen 1920, ss. 1150) oraz Kral (Serbsko-němski słownik hornjotužiskeje rěče/Sorbisch-deutsches Wörterbuch der Oberlausitzer sorbischen Sprache, Budyšin 1927-1931). W słownikach tych znajduje się wiele neologizmów (częściowo także indywidualizmów leksykografów) utworzonych na podstawie górnołużyckich modeli sło- 
wotwórczych lub wzorowanych na słownictwie słowiańskim (głównie czeskim). Obaj leksykografowie byli purystami językowymi, tj. dążyli do usunięcia z górnołużyckiego jak największej liczby słów pochodzenia niemieckiego. Częściowo nowe słownictwo wyekscerpowali z prasy łużyckiej. Jednak w większości nie funkcjonowało ono już w piśmiennictwie łużyckim lat 30. i po drugiej wojnie światowej.

\section{Normalizacja i kodyfikacja górnołużyckiego i dolnołużyckiego po drugiej wojnie światowej}

Po 1945 roku (a zwłaszcza od połowy lat 50.) kilkakrotnie normalizowano ortografię, morfologię, składnię i leksykę obu języków łużyckich. Prace kodyfikacyjne uległy przyspieszeniu, gdy w 1951 roku powstały dwie szczególnie ważne w sorabistyce instytucje naukowe: uniwersytecki Institut sorabistyki/Institut für Sorabistik w Lipsku oraz Institut za serbski ludospyt/po 1990 roku: Serbski institut/Institut für sorbische Volksforschung/Sorbisches Institut w Budziszynie, jak również w 1952 roku powołano Komisję Językową, która działała w dwóch zespołach: górnołużyckim i dolnołużyckim. Wyniki normalizacji dokumentują publikacje normatywne, tj. gramatyki i różnego typu słowniki.

\subsection{Normalizacja i kodyfikacja języka górnołużyckiego}

Najwcześniej przystąpiono do nowej kodyfikacji ortografii, ponieważ nawet największe słowniki pierwszej połowy XX wieku, Słownik F. Rězaka (1920) i Słownik J. Krala (1927-1931), dosyć znacznie różniły się pod względem ortografii. Ważne ustalenia ortograficzne (Rjadowanje serbskeho prawopisa) opublikowano w 1948 roku. Słownik ortograficzny z 1962 roku w postaci powielonego maszynopisu potraktowano jako podstawę do dyskusji. W 1970 roku ukazała się jego poprawiona wersja; później wydawano ten słownik kilkakrotnie ze zmianami (Lewaszkiewicz 2016; Bura 2016). W 1974 roku po raz pierwszy opublikowano zasady pisowni i interpunkcji Pawoła Völkela: Hornjoserbska ortografija a interpunkcija - prawidła (Bautzen).

W 1951 roku gramatykę szkolno-normatywną J. Krala zastąpiła podobna w założeniu gramatyka Pawoła Wowčerka Kurzgefasste obersorbische Grammatik (Bautzen). Na gramatykę naukowo-normatywną czekano dosyć długo: Hinc Šewc, Gramatika hornjoserbskeje rěče, 1. zwjazk, fonematika a morfologija (Budyšin 1968); Schuster-Šewc, Gramatika hornjoserbskeje rěče, 2. zwjazk, syntaksa (Budyšin 1976). Wysoki poziom naukowy reprezentuje obszerna gramatyka obejmująca jednak tylko morfologię: Helmut Faßke, Grammatik der obersorbischen Schriftsprache der Gegenwart. Morphologie/Gramatika hornjoserbskeje spisowneje rěče přitomnosće. Morfologija, verfaßt unter Mitarbeit von Siegfried Michalk (Bautzen 1981). Dzieło to funkcjonuje również jako gramatyka normatywna. W 2003 roku H. Faska [Faßke] opublikował gramatykę obejmującą cały system gramatyczny: Pućnik po hornjoserbšćinje (Bautzen). Ma ona charakter normatywny - może służyć jako podręcznik dla uczniów i nauczycieli szkół średnich, jako podręcznik dla studentów sorabistyki i slawistyki, jak również jako kompendium naukowe. 
Normalizacją powojennego słownictwa górnołużyckiego zajął się Filip Jakubaš (Hornjoserbsko-némski słownik, Budyšin 1954). Leksykograf jednak zamieścił w nim zbyt dużo archaizmów (Lewaszkiewicz 2013), neologizmów F. Rězaka (Lewaszkiewicz 1980) i J. Krala (Lewaszkiewicz 2017) oraz powojennych neologizmów. Bardziej realistyczny materiał wyrazowy zawierają dwa słowniki terminologiczne: obejmujący terminologię wielu dziedzin wiedzy (Pomocny terminologiski słownik: Němsko-serbski, Berlin 1957) oraz dotyczący terminologii rolniczej: Ratarska terminologija Rudolfa Jenča (Budyšin 1966). Słownikiem dokumentującym rzeczywiście używane słownictwo jest wspomniany już słownik ortograficzny z 1970 roku i jego późniejsze edycje. W podnoszeniu kultury językowej od 20 lat szczególne znaczenie ma dwutomowy słownik niemiecko-górnołużycki (Deutsch-obersorbisches Wörterbuch/Němsko-hornjoserbski słownik, Bautzen 19891991), opracowany pod redakcją Helmuta Jenča. Całość współczesnego słownictwa górnołużyckiego obejmuje przygotowywany w Budziszynie Deutsch-obersorbisches Wörterbuch.

\subsection{Normalizacja i kodyfikacja języka dolnołużyckiego}

Mniej intensywny charakter miała powojenna kodyfikacja języka dolnołużyckiego. W 1952 roku wznowiono gramatykę B. Šwjeli z 1906 roku (w opracowaniu F. Mětška). Została ona zastąpiona dopiero w 1976 roku przez nowoczesną gramatykę Pětra Janaša (Niedersorbische Grammatik für den Gebrauch der Sorbischen Erweiterten Oberschule, Bautzen).

Skromne były również początki powojennej leksykografii dolnołużyckiej. Wydano dwa nieduże słowniki B. Šwjeli: Deutsch-niedersorbisches Taschenwörterbuch (Bautzen 1953); Dolnoserbsko-němski słownik (Budyšyn 1961). Oba słowniki przygotował do druku Alfred Mitaš. Ukazał się również - wzorowany na słowniku górnołużyckim - dolnołużycki słownik terminologiczny: Pomocny terminologiski słownik: Němsko-dolnoserbski (Budyšyn 1960). Do podniesienia kultury języka dolnołużyckiego w zakresie słownictwa przyczyniły się dwa podręczne słowniki: słownik dolnołużycko-niemiecki Manfreda Starosty (1985) oraz słownik niemiecko-dolnołużycki P. Janaša (1990).

Ważnym wydarzeniem w dziejach leksykografii dolnołużyckiej stało się opublikowanie obszernego słownika (liczącego 45 tys. haseł) M. Starosty: Dolnoserbsko-nimski słownik/ Niedersorbisch-deutsches Wörterbuch (Bautzen 1999). Nie wydano dotąd specjalnego słownika ortograficznego, ale jego funkcję pełnią słowniki dwujęzyczne dolnołużycko-niemieckie i niemiecko-dolnołużyckie. Istnieje za to osobno wydany zbiór zasad pisowni i interpunkcji w opracowaniu M. Starosty: Dolnoserbska ortografija a interpunkcija - pšawidta (Bautzen 1976).

Szczególną rolę w leksykografii dolnołużyckiej odegra z pewnością powstający w Chociebużu Deutsch-niedersorbisches Wörterbuch. Zespół leksykografów dołączy do tego słownika nagrania dźwiękowe słownictwa.

Dodajmy jeszcze, że po drugiej wojnie światowej realizowano ideę zbliżenia dolnołużyckiego do górnołużyckiego - głównie w zakresie ortografii. Po 1990 roku zmieniono zasady pisowni dolnołużyckiej, które polegały głównie na usunięciu „wpływów” górnołużyckich. O tych sprawach informują m.in.: Starosta (1998), Pohončowa (2000), Marti (2007). 


\section{Normalizacja i kodyfikacja a problem intelektualizacji dawnych dialektów dolnołużyckiego i górnołużyckiego}

Problem kształtowania się łużyckich języków literackich ukazywali dotychczas sorabiści w monografiach języka poszczególnych zabytków i autorów, jak również w syntetycznych artykułach. Ograniczę się (rezygnując z podania danych bibliograficznych) do wymienienia części nazwisk: Heinz Schuster-Šewc, Frido Michałk (Siegfried Michalk), Helmut Faska, Helmut Jenč, Gerald Stone, Stanisław Stachowski, Marian Radłowski, Sonja Wölkowa, Jana Šołćina/Schulz, Fabian Kaulfürst. W tej dziedzinie jest jeszcze dużo do zrobienia. W porównaniu jednak z innymi językami słowiańskimi historia kształtowania się łużyckich języków literackich jest stosunkowo słabo opracowana. Wynika to głównie z tego, że niewielu lingwistów zajmuje się językową analizą tekstów, chociaż Łużyczanie stworzyli bogate piśmiennictwo.

W większości opracowań historycznojęzykowych dosyć dużo mówi się o normalizacji i kodyfikacji, natomiast brak rozważań o pogłębiającej się w miarę upływu czasu intelektualizacji dialektalnego materiału językowego, tj. zwiększającej się zdolności języka do zaspokajania wyższych potrzeb komunikatywno-kulturalnych. Odnotowuje się silne wpływy języka niemieckiego na system leksykalny i system gramatyczny języków łużyckich, ale zabrakło stwierdzenia, że to właśnie kontakty dialektów ludowych z językiem niemieckim były główną siłą sprawczą - właściwie do połowy XIX wieku - formowania się łużyckich języków literackich. W tym zakresie ważny, ale - w porównaniu z niemieckim mniej istotny był wkład języka czeskiego. Podstawy łużyckich języków literackich stworzyli ludzie dwujęzyczni - Łużyczanie i Niemcy znający łużyckie dialekty ludowe (ewentualnie w XVII-XVIII wieku język piśmiennictwa łużyckiego) oraz wysokoprestiżowy (tj. sprawny funkcjonalnie) język niemiecki. Niektórzy wykształceni Łużyczanie i Niemcy, posługujący się łużyckim (głównie duchowni), znali również łacinę, grekę i hebrajski. Efekty intensywnych kontaktów łużycczyzny z niemieckim miały też z drugiej strony negatywny charakter, przejawiający się w nadmiarze germanizmów leksykalnych i gramatycznych. Zastąpienie ich rodzimymi środkami językowymi oraz zapożyczeniami słowiańskimi było przynajmniej częściowo słuszne. Na pozytywną ocenę zasługuje w związku z tą sprawą umiar językowy pisarzy, publicystów, nauczycieli, duchownych łużyckich itd., którzy przeciwstawili się skrajnym tendencjom purystycznym.

Kilkakrotnie pisałem o roli języków wysokoprestiżowych w kształtowaniu literackich języków słowiańskich (Lewaszkiewicz 1992a, 1992b, 1995, 1996). W tym miejscu chciałbym przywołać kilka początkowych akapitów z mojego artykułu (Lewaszkiewicz 1992a: 133-134).

Proces formowania się języka literackiego polega na doskonaleniu się ogólnej sprawności funkcjonalno-językowej (tj. sprawności leksykalno-składniowo-stylistycznej) tworzywa dialektalnego oraz na kształtowaniu się ponaddialektalnych norm językowych. Jak się wydaje, na początku tego procesu najważniejszą sprawą jest wzrost ogólnej sprawności językowej, która jest główną lub jedyną cechą odróżniającą powstający język literacki od mowy czysto ludowej, tendencje normalizacyjne bowiem pojawiają się raczej później, stając się stopniowo współwyznacznikiem literackości języka. Ostatecznie jednak obie strony procesu formowania się języka literackiego należy uznać za tak samo ważne, ponieważ odpowiedni poziom środków językowych jest warunkiem powstania dobrze funkcjonujące- 
go narzędzia wyrażania myśli, normalizacja językowa zaś jest warunkiem ukształtowania się ogólnego języka narodu.

Rozpatrując problem formowania się języków literackich, historycy języków słowiańskich i europejskich biorą pod uwagę obie strony procesu, ale na plan pierwszy zdecydowanie wysuwają dialektalną genezę języków literackich i zagadnienie ich normalizacji. Można zatem mówić o przecenianiu lub wręcz o absolutyzowaniu wyników dialektologii historycznej w objaśnianiu pochodzenia języków literackich. Nie zadowala też ocena roli kontaktów z językami wyższej kultury w kształtowaniu języków literackich, gdyż kontakty te traktuje się tylko jako dodatkowe czynniki wspierające ważniejsze, tj. rodzime siły sprawcze doskonalenia ogólnego potencjału językowego. Moim zdaniem, w kompleksowym spojrzeniu na początki rozwoju języków literackich nie znalazły odpowiedniego zastosowania główne pojęcia teorii kontaktów językowych - dwujęzyczność/wielojęzyczność, interferencja oraz konwergencja.

Uważam, że kontakty dialektów ludowych z językami wyższej kultury (np. łaciną, greką, niemieckim, czeskim) były głównym czynnikiem sprawczym wzrostu sprawności językowej kształtujących się języków literackich europejskiego kręgu kulturowego. Rodzime wzorce językowe stały się najważniejszą siłą napędową rozwoju leksykalno-składniowo-stylistycznego znacznie później, np. w historii polszczyzny chyba dopiero w połowie XVI wieku. Dialekty ludowe intelektualizowały się podczas kontaktów z językami wysokoprestiżowymi, tj. wzbogacały się o nowe jednostki leksykalne (zwłaszcza o słownictwo abstrakcyjne), o nowe znaczenia wyrazowe, związki frazeologiczne, afiksy obcego pochodzenia i konstrukcje składniowe. Kontakty językowe przyczyniały się też do specjalizacji spójników (głównie wprowadzających zdania podrzędne), wyrabiały umiejętność posługiwania się zdaniami współrzędnie i podrzędnie złożonymi, różnymi typami zdań wielokrotnie złożonych i środkami językowymi wpływającymi na spójność składniową tekstu, kształtowały odmiany stylistyczne języka. W wyniku kontaktów językowych powstawały teksty mieszane językowo, tj. poświadczające interferencyjne oddziaływanie języka/języków wyższej kultury. Zintelektualizowane dialekty stawały się więc narzędziem kultury grecko-rzymskiej, narzędziem logicznego myślenia. Język czysto ludowy nie nadawał się do pełnienia takiej funkcji.

Do intensywnych kontaktów językowych dochodziło dzięki ludziom dwu- i wielojęzycznym, znającym miejscowe dialekty ludowe i jakiś język wysokoprestiżowy, np. łacinę, grekę, niemiecki.

Za główne czynniki sprawcze wstępnego etapu rozwoju języków literackich uznawałem dotychczas intelektualizację (najważniejszy czynnik) oraz normalizację/standaryzację. Pod wpływem lektury artykułu Tomasza Lisowskiego (2018) dołączam trzeci czynnik: grafizację (dotyczącą rękopisów oraz druków).

Uważam, że ten sposób myślenia powinien się zadomowić również w sorabistyce.

\section{Uwagi końcowe}

Języki łużyckie (głównie dolnołużycki) były i są najsłabiej unormowanymi językami słowiańskimi. Większe rozchwianie norm cechuje tylko niektóre tzw. mikrojęzyki słowiańskie. Przypomnę, że Aleksander D. Duliczenko, ich wybitny znawca, wymienił 
ostatnio (Duliczenko 2003-2004) 18 takich języków i 2 projekty/eksperymenty, np. rusiński, chorwacko-gradiszciański, chorwacko-molizański, rezjański, banacko-bułgarski, karpacko-rusiński/łemkowski, pomacki, zachodniopoleski. Sądzę, że zaliczenie dolnołużyckiego i górnołużyckiego do mikrojęzyków słowiańskich jest słuszne.

Konieczne jest ściślejsze unormowanie języków łużyckich i skodyfikowanie norm językowych w słownikach poprawnościowych, które powinny powstać w przyszłości. Istnieje potrzeba wskazania norm wzorcowych i konieczność szerokiej akceptacji dla norm użytkowych, tj. mniej starannych wariantów norm, dobrze pełniących jednak funkcje komunikatywne. W łużyckiej sytuacji językowej, w której najważniejszą sprawą jest przetrwanie dolnołużyckiego i górnołużyckiego, niezbędne jest dosyć liberalne podejście do problemów kultury języka.

\section{Bibliografia}

Bura R., 2015, Zapożyczenia czeskie w słowniku Pfula. Terminologia naukowa, Kraków.

Bura R., 2016, Rozdíly mezi čtvrtým a pátym vydáním ortografického Völkelova slovníku, w: Pražské sorabistické studie II.: K 360. výročí narození pražského sochaře lužickosrbského původu Matěje Václava Jäckela (1655-1738), red. P. Kaleta, M. Černý, E. Papcunová, Praha, s. 243-252.

Дуличенко A.D., 2003-2004, Славянские литературные микроязыки. Образцы текстов, I-II, Тарту.

Faska H. (red.), 1998, Najnowsze dzieje języków słowiańskich: Serbšćina, Opole.

Gutschmidt K. (red.), 2002, Möglichkeiten und Grenzen der Standardisierung slavischer Schriftsprachen in der Gegenwart, Dresden.

Lewaszkiewicz T., 1980, Propozycje leksykalne w Słowniku Rězaka, „Lětopis” 27/1, s. 47-54.

Lewaszkiewicz T., 1992a, Rola kontaktów językowych we wstęnym okresie formowania się stowiańskich języków literackich (na tle ogólniejszym), w: Z polskich studiów slawistycznych. Seria 8: Językoznawstwo, Warszawa, s. 133-138.

Lewaszkiewicz T., 1992b, Rola przekładów Biblii w formowaniu języków literackich europejskiego kręgu kulturowego, w: Biblia a kultura Europy I, red. M. Kamińska, E. Małek, Łódź, s. 232-248.

Lewaszkiewicz T., 1994, O potrzebie nowego spojrzenia na geneze polskiego języka literackiego (z uwzględnieniem tła ogólnoeuropejskiego), w: Studia historycznojęzykowe I, red. M. Kucała, Z. Krążyńska, Kraków, s. 213-220.

Lewaszkiewicz T., 1995, Łużyckie przekłady Biblii. Przewodnik bibliograficzny, Warszawa.

Lewaszkiewicz T., 2007, Sporne problemy języka dolnołużyckiego przekładu Nowego Testamentu Jakubicy (1548), w: Z polskich studiów slawistycznych. Seria 11: Językoznawstwo, Warszawa, s. $111-118$.

Lewaszkiewicz T., 2013, Hasła kwalifikowane $w$ górnołużycko-niemieckim słowniku Jakubaša (1954), w: „Acta Slavica Estonica” III. „Slavica Tartuensia” X, Tartu, s. 124-139.

Lewaszkiewicz T., 2016, Jazykové a redakčni rozdily mezi prvním (1970) a čtvrtým (1981) vydáním Völkelova slovníku, w: Pražské sorabistické studie II. : K 360. výročí narození pražského sochaře lužickosrbského původu Matěje Václava Jäckela (1655-1738), red. P. Kaleta, M. Černý, E. Papcunová, Praha, s. 229-242.

Lewaszkiewicz T., 2017, Статьи с оценочными пометами в верхнелужицком словаре Ю. Краля (1927-1931) на фоне их соответствий в других словарях, w: Миноритарные $u$ региональные языки $u$ культуры Славии, отв. ред. С.С. Скорвид, Москва 2017, с. 174-185. 
Lisowski T., 2018, Intelektualizacja i jej pochodne: standaryzacja oraz grafizacja jako czynniki ksztattujace polszczyznę literacka w początkach ery typograficznej, w: Historia języka w XXI wieku. Stan i perspektywy, red. M. Pastuch i M. Siuciak przy współpracy K. Wąsińskiej i W. Wilczek, Katowice, 109-125.

Marti R., 2007, Ó $w$ dolnoserbšćinje, Forschungsbericht Nr. 11. Institut für Phonetik - Universität des Saarlandes, Saarbrücken.

Pohončowa A., 2000, Procowanje wo pśibliženje gorno- a dolnoserbskego pšawopisa po lěśe 1945, „Lětopis“ 47/1, s. 3-21.

Pohontsch A., 2002, Der Einfluss obersorbischer Lexik auf die niedersorbische Schriftsprache. Ein Beitrag zur Entwicklungsgeschichte der niedersorbischen Schriftsprache, Bautzen.

Starosta M., 1998, Pismik ó $w$ dolnoserbšćinje, „Serbska šula“ 6, s. 111-112.

Толстой Н.И., 1988, История и структура славянских литературных языков, Москва.

Urbańczyk S. (red.), 1977, Wariancja mowy we współczesnych słowiańskich językach literackich, Wrocław.

Wölke S., 2005, Geschichte der sorbischen Grammatikschreibung. Von den Anfängen bis zum Ende des 19. Jahrhunderts, Bautzen.

TADEUSZ LEWASZKIEWICZ

\section{The issues of standardization and codification in the history of the Upper Sorbian and Lower Sorbian languages}

\section{Summary}

The subject of the article is a process of standardisation and codification of the Upper Sorbian and Lower Sorbian languages. The author enumerates and reviews the most important grammars and dictionaries codifying the Sorbian language, stresses the influence of the Maćica Serbska cultural and educational associations on arriving at a common Upper Sorbian standard and demonstrates the role of the Czech language in developing Sorbian standards.

Keywords: Lower Sorbian language, Upper Sorbian language, standardization and codification of Sorbian languages, Sorbian grammars, Sorbian lexicography, analogous spelling, K. B. Pful, intellectualization of language 